\title{
NATIVIZATION AND USE OF BORROWING WORDS IN BAHASA INDONESIA
}

\author{
Saifuddin Ahmad Husin
}

Email: anang_saifuddin@yahoo.com

Jurusan Pendidikan Bahasa Inggris Fakultas Tarbiyah IAIN Banjarmasin

Alamat Korepondensi: Jalan Pramuka Gg. Kayu Manis Rt 08 No. 8 Banjarmasin 70249

\begin{abstract}
Bahasa Indonesia, the national language of Indonesia, has traditionally borrowed items from the world's classical languages, Sanskrit and Arabic. However, elements from European languages, especially English, have also massively influenced the expansion of Bahasa Indonesia's lexicons. Massive influx of the latter has caused a controversy among Indonesia's linguists and other experts. Should greater loan be made from the former, as traditional source of borrowings, or should Bahasa Indonesia borrow more from the latter, as the language of modernity symbol in Indonesia? The controversy has been cleverly resolved with the adaptation and combination of elements of seemingly conflicting sources to serve specifically Indonesian objectives. In the lexical modernization of Bahasa Indonesia, despite the apparent irreconcilability of the two approaches to the use of foreign borrowings, Indonesians are effectively utilizing in a systematic manner the diverse foreign languages that their rich and varied history has made available to them.
\end{abstract}

\section{Keywords}

Lexical Borrowing, Nativization, Bahasa Indonesia, Language Modernization

\section{Introduction}

Bahasa Indonesia had been adopted as a national language since 1928, although Indonesia did not obtain its independence until 1945. The adotion of Bahasa Indonesia as a national language was a part of opposition to the Dutch colonialism. When Indonesia was proclaimed independent in 1945, Bahasa Indonesia had already become the primary pan Indonesia language, and was declared Indonesia's single national official language. Since the independence of Indonesia the lexicon of Bahasa Indonesia has been expanded by a large number of direct borrowings from foreign languages. The flowing in of foreign words has triggered a major controversy among Indonesian linguists; should such loan-words from nonIndonesian languages come primarily from foreign languages from which Bahasa Indonesia has traditionally borrowed, especially Sanskrit and Arabic, or should greater use be made of the European languages, particularly English, the socalled language of modernity symbol in Indonesia? With regard to the European languages, the English language has now taken over the position of the Dutch language. Soon after the independence of Indonesia the teaching of the Dutch language was terminated and has been practically taught and used in a very limited domain. The only domain in which Dutch is still extensively used is in the area of law. 


\section{Conclusion}

The controversy concerning the use of European or non-European languages is generally resolved according to the domain and the function of the borrowing. A further striking example of how these criteria determine which foreign words enter Bahasa Indonesia is a small set of hybrids containing borrowings from both Sanskrit, Arabic, and European languages. For example, one government of Indonesia during the New Order Era called itself the Kabinet Karya, 'Work Kabinet', a compound in which the European borrowing kabinet connotes modernity while the Sanskrit root karya, as opposed to Malay kerja, links to the government with its prestigious Hindu predecessors. Similarly, the dwifungsi, 'two functions', the military doctrine during the New Order regime, in which the Sanskrit prefix $d v i$ legitimizes the fact that in addition to its military role, the Indonesia armed forces was also performing the modern function of coordinating the economic, social, and cultural development of the nation. As previously mentioned, Bahasa Indonesia also utilizes foreign words altogether to express concept inexist or not prestigious if otherwise expressed in Malay words such as the name of Indonesian flag bendera dwiwarna, 'bicolor flag' in which Spanish/Portuguese bandera is used in juxtaposition with Sanskrit $d v i$, two, and varna, color.

These demonstrate a pattern that has pervaded Indonesian society and culture throughout Indonesia's history: the adaptation and combination of elements of seemingly conflicting sources to serve specifically Indonesian objectives. In the lexical modernization of Bahasa Indonesia, despite the apparent irreconcilability of the two approaches to the use of foreign borrowings, Indonesians are effectively utilizing in a systematic manner the diverse foreign languages that their rich and varied history has made available to them.

\section{REFERENCE}

Alisyahbana, Sutan Takdir. 1976. Language Planning and Modernization: The Case of Indonesian and Malaysian. Mouton: The Hague.

Ball, M. 1971a. "Prestige Languages and Word Borrowing: The Changing Status of Arabic and English in Kenya, in Studies in African Linguistics, Supplement 2. pp. 131-137.

Beg, Muhammad Abdul Jabbar. 1979. Arabic Loan-words in Malay. Kuala Lumpur: The University of Malaya Press.

Bloomfield, L. 1933. Language. London: George Allen \& Unwin Ltd.

Crystal, David. 1991. A Dictionary of Linguistics and Phonetics. Cambridge, Massachusetts: Basil Blackwell.

Devereux, G \& Loeb, E.M. 1943. "Antagonistic Acculturation”, in American Sociological Review, Vol. 8, pp. 133147.

Gonda, J. 1973. Sanskrit in Indonesia. New Delhi: International Academy of Indian Culture.

Hasselmo, N. 1961. American-Swedish: A Study in Bilingualism, Ph.D dissertation, Harvard University.

Haugen, E. 1953. The Norwegian Language in America, 2 Vols, Philadelphia: University of Pennsylvania Press.

1958. "Language Contact", in Proceedings of the $8^{\text {th }}$ International Congress of Linguists (ed.) Siversten, Oslo: Oslo University Press. pp. 771-785.

Hoeningswald, H.M. 1962. "Bilingualism, Presumable Bilingualism and Diachrony," in Anthropological Linguistics Vol. 4 (1) pp. 1-5.

Jespersen, O. 1922. Language, its Nature, Development and Origin. London: George Allen \& Unwin Ltd.

Quinn, G. 1975. Some Observations on English Teaching Policy in Indonesia. Jakarta: Warta Scienta.

Sapir, E. 1921. Language. New York: Harcourt, Brace \& World, Inc. 
LWNGUA Volume 6, Nomor 2, Agustus 2011 - ISSN 1693-4725

Weinreich, U. 1953. Language in Contact. New York: Linguistics Circle of New York. 